\title{
The Relationships between Conflict Management Styles, Job Satisfaction and Organizational Commitment among Workers in Public and Private Sectors
}

\author{
Khaled Ahmed Galal Ahmed \\ Department of Psychology, Modern Science University, Dubai and Faculty of Arts El-Minia University, Egypt
}

Copyright (C) 2015 Horizon Research Publishing All rights reserved.

\begin{abstract}
Conflict is inevitable in all living organisms, it is a natural phenomenon and social occur among humans wherever and when they are. There is evidence of existence of conflict since the beginning of the creation of what happened between Adam's Son Cain and Abel, and ended up killing someone. The study aimed to investigate relationships between styles of managing conflicts, job satisfaction and organizational commitment in a sample of private, and public organizations. The study conducted on a sample of (329) persons, $198(60.2 \%)$ public organization who are employees of a university and private sector sample of $131(39.8 \%)$ workers in different industrial factories. Used conflict management styles questionnaire prepared by the researcher, besides job satisfaction and organizational commitment. MANOVA statistics such as the differences between the two groups (private, public), also, differences between two groups correlation coefficients. The results showed significant differences between the two groups on the style of avoidance, there are no significant differences in satisfaction and organizational commitment. The Results of the study also showed a positive relationship between job satisfaction and organizational commitment in a private sector sample only. It also found significant relationships between conflict management styles and both job satisfaction and organizational commitment, in public sample than private sector sample. Finally, there were differences between correlation coefficients between conflict management styles showed job satisfaction, organizational commitment, implications of the study for future research, as well as practical implications.
\end{abstract}

Keywords Conflict, Conflict Management Style, Job Satisfaction, Organizational Commitment, Private and Public Sectors

\section{Introduction}

Conflict is inevitable in all living organisms, it is a natural phenomenon and social occur among humans wherever and when they are. Styles of conflict management met recently increased attention because of the perception that prevailed is that conflict, evil nor harvested from only loss, has changed that view seemed seen positively in the conflict wailing, which leads to creativity, productivity, job satisfaction and loyalty to the organization. So conflict described as "the life of the organization," as that organization without a conflict does not exist, this conflict does not exist without members depends on each other's in completing certain tasks. In this regard, managers spend on average about $20 \%$ of their time in resolving conflicts between themselves and others [1] p. 496) [2] p. 651). Conflict effects output of group work and may prevent deep connections, when struggle like any administrative process, therefore, must manage. The Impact of conflict in the workplace is not located, according to performance or productivity, but also has harmful, dangerous to health and self-wellbeing. The Conflicts associated with depression among employees' negative emotional situations, psychosomatic complaints, dissatisfaction with life, overheating and psychological morbidity [3] p. 267) [4]. A Social field in which we work gives us not only support, but also the main source of pressure, poor relations of trust, attention and support at least when an individual is facing problems. It appears in psychosomatic complaints, work dissatisfaction and wish to leave it. Conflict research and theory, focused traditionally on conflict management in relation to personal strategies and effective work teams and productivity, and to some extent there was little interest in the "soft" outputs like satisfaction, organizational commitment, leaving work on purpose, occupational health and self-wellbeing, This may isolate the conflict theory and research on a larger scale in organizational psychology and organizational behavior research. It also hinders practical work where it remains uncertain to know how interventions affect not only conflict or effectiveness, but also in occupational self-satisfaction [5]. Consideration could be given to conflict as a complex phenomenon and multi-faceted. The conflict has a long history of Giants 
scientists, Darwin, Marx and Freud, who contributed to the intellectual climate of beginnings of social psychology. Darwin has emphasized the idea of "competition of striving to stay" and survival more worthy. Marx stressed the idea of "class struggle" and conflict between middle class (bourgeoisie) and working class (proletariat), Freud in his theory of psychosexual growth, where struggling constants between the biological rooted infantile id and the socially determined, internalized parental surrogate, the superego [6] P.13)..

\section{Conceptual Review}

Conflict history as old as humanity, itself says (Allah) in Holy Qur'an "And recite to them the story of Adam's two sons, in truth, when they both offered a sacrifice [to Allah], and it accepted from one of them but not accepted from the other. Said [the later], "I will surely kill you." Said [the former], "Indeed, Allah only accepts from the righteous [who fear Him] Surat Al Mā'idah (27) [7]. With advent of the industrial revolution, scientists began work in studies for increasing effectiveness of organizations then productivity. Classical theories have focused on isolating conflict and control it through work of organizational hierarchy for role distribution, workers selections, division of labor and create harmony or homogeneity among workers in organizations, including not allow existence of conflicts. Pioneers of this period (Taylor, 1911, and Henry Fayol 1916, and Max Weber in 1929 and Mary Parker Follett 1926), all except Follett, which focused on the importance of conflict in the organization, she also emphasized the importance of integrative style (problem-solving) in managing organizational conflict, and said other aspects styles to resolve conflicts such as suppression, avoidance, control and compromising, which deemed effective styles in dealing with conflicts [8] PP.8-11). It influenced by the following thought to conflict management and foundation it's built upon Black and Mouton administrative grid. Classical theory updated neoclassical have confirmed Alton Mayo (1933) who led the movement of human relations and stressed the need to cut conflict or isolated to increase the effectiveness of the organization. Finally, the modern theory of conflict and which considers that people motivated by a wish to reduce tension, tension is normal and desirable if it's associated with growth and upgrading [8]. Conflict does not seem to surface as a result of opponent and differences between people, so there is a conflict occurs when an intensity threshold that tells parties to conflict reaches to level that there is a conflict between them. In other words parties become aware, they must sharp and dangerous enough. Conflict varies from person to person according to personal style, tolerant and dominant, this makes some people more conflict prone than others. Hence, we can define conflict as a process by which one of the parties is aware that his interests have opposed or resisted or been adversely affected party or other group. Process of conflict explodes by differences in goals, values or because lack of resources, transparency and communication. In fact a number of sequential events that ultimately lead to the conflict begin with frustration when there is no agreement, ended by conflict behavior [9] p. 332). Where conflict starts from a lack of agreement or difference in values, goals and interests result in tension accompanied by frustration, for not achieving targets generated by perceptions of conflict to one of parties, which could lead to severe emotion (anger or fear), explicit conflict with another party or may realize the existence of conflict, but it is not up to the explicit conflict with some people either as a feature of personal tolerance or to transform the conflict into inside. Conflict arises due to regulatory factors or because of personal factors among workers. Baron has noted [10] pp. 202-208), another type of causes conflict, a conflict between people, where the attention focusing on organizational reasons, newly attention to personal conflicts began where he found it expensive in time and effort which reflected negatively on production. Among the multiple factors of conflict, so-called earlier Grudges between workers when angry people affect other people, these others are aware of loss of confrontation (find them foolish) and then develop negative attitudes towards those responsible for these outputs, and one of the results that they devote their time and largest effort in planning task or search for these mental mistakes or imaginary realism has these grudges last for years. It is causing conflict between people as well as so-called Faulty attribution where poor perception of behavioral motivations of others party conflict, and why they acted in this way? In such cases, frustrating or opposition party is trying to decide why the disposal of his opponent this way? There is also what is known as wrong contact, Faulty communication in work may continue with some people from each other in ways that tinged anger, agitation, harassment, and even if it was unintentional. This lack of communication they returned for lack of clarity and use of inappropriate criticism (especially between superior and subordinate), convey it to recipients of negative feedback, which makes them more angry instead of helping them to do a job well done, it's called destructive criticism. As (Baron) shown that some people more likely to fall into more than one organizational conflict, such as, show need for affiliation and held friendly relations with others, associated with a positive preference for addressing conflict through the style of obliging, and negatively associated with a preference for dealing with conflict over competition style. It also found that people who have a high need to control estimated their colleagues that they are more competitive and less willing to use the style of compromising for those who have a low need for control. It also found that type A personalities and self-monitoring have an importance of issue of handling conflicts, they are more competitive and aggressive in their dealings with others, than type (B) persons, so it has expected that such one may fall into conflict quickly. And those who characterized by high self-monitoring have sensitivity to affecting others and able to reconcile their behavior in every situation they face. Rahim has addressed [8], pp. 21-23) the sources of conflict differently from "Baron" view, where he talked about the conflict 
classifications according to interests, values and goals for to making a better understanding of the nature of conflict and its causes.

\section{Styles of handling conflict}

In fact, there is no specific definition agreed upon by scholars because of different areas of specialization. First, we will focus on the basic concept and integrate it with other terminology for constructing an integrative view. Conflict is idiomatically different from the concepts of the dark side or grim, such as aggression, uncouth, delinquency, bullying or tyranny. in spite of these concepts involved in fact that conflicting groups are interdependent each other and have different interests, values, and beliefs, but does not need that hurt group, other group and does not need to cause negative outcomes.[11] reported that organizational conflict to better understand is that "constitute a dynamic process of organizational behavior." [12], p.72) define conflict as an "intense image or severe differences between two or three parties each depends on the others, on basis of inconsistencies in needs, desires, values, beliefs and attitudes. [8], p.19). [13], p.122) defined the conflict as "an interactive process manifests itself in the form of disagreement and conflict within social entities like person, group, or organization." as defined by [14], p. 333) "internal conflict caused by differences in values, ideas or feelings between two or more people. [15], p.4) defined the conflict as a "perceived differences and concerns among a group of people." [16], p.6) defined it as "a process that begins when a person or group realizes differences or conflicts around interests, sources, beliefs and values within-person or with other people or group." [17], p.5), defined it as "extent of agreement or conflict between people and groups around interests, beliefs, and values." [18], p. 149) defined the conflict as "a process by one of parties is aware that concerns or interests opposed or resisted or been affected by party or group". [10], p. 198) review a number of definitions of the concept of conflict across literature and concluded that the definitions are not same. It focused on different definitions that we can summarize as follows:

1. The conflict involves conflicting interests between opposing people or groups, in point of gains equal to losses (Zero-sum).

2. These conflicting interests should perceive to show existing of conflict Recognized.

3. A conflict involves Beliefs between both sides of conflict, a Party resisted or already resisted beliefs of another party.

4. Conflict is Process evolves through relationships between people or groups, which reflects ancient relations between them and the context in which they occurred.

5. Actions include events such opposition to the goals of others.

It is observing from the previous definitions of conflict, it focused on three dimensions: cognitive dimension which represented in cognition and cognitive components: interests, beliefs and values, and emotional dimension, which is subject of negative or positive feelings about conflict object, and behavioral dimension which represents a reaction to opponents. As well as we can figure components of conflict concepts: first, conflicting goals between the parties and subject of conflict, but there would have been a conflict. Second, relying on each other (interdependence) to complete the tasks, meaning depends on work done by one of groups or people on the work being done by another group. Third, interaction, and methods of communication between conflicting parties. There is another concept which is conflict management, it involves dealing with differences between people or groups in conflict of interests and behavior, which may weaken health, satisfaction and diminished productivity for both members and organizations. It also helps to understand better complex problems. [19], p. 96). Finally concept of conflict management styles refers to a way in intent or usual way for a person when dealing with conflicts. It also represents a unique way of dealing with conflicts which determined by individual attention self and others. [20], p. 82), Over history of psychology and organizational behavior appeared several models to discuss conflict between parties, appeared to form a two, three, four, and five dimensions we can summarized as follows, [8] pp. 24-27): two model dimensions: Deutsch proposed (1949) a model for dealing with social conflicts in which cooperation versus competition, called on struggles to compete technically zero-sum games or negative sums, since results are positive for one of the parties and negative side to another. In fact, there is no regulatory cooperation, not competition, Deutsch has said that most influenced the relationship of cooperation in competition relationship when dealing with conflicts. Three-dimensional model: [21], based on factor analysis of measure items of organizational conflict management, where three styles are: non-confrontational (oblige), complementary and control. Also, after a review of styles of conflict that clustered in three styles: avoidance, competition and cooperation (integration). [22]. after analyzing 25 saying or judgment to resolve conflict patterns and reached three factors: forcing, oblige and confrontation [23]. There are other scientists classified styles of conflict into three dimensions, such as [24], cooperation, oblige and competition. Another scientist found three factors: Solve the problem, yielding and avoidance [25]. But the question remains, are these styles derived from administrative work? Is it useful for organizations in conflict management? Four dimensions model [26]: based on empirical and laboratory studies: Yielding, problem solving, Inaction and Contending, formed these styles on the basis of dual dimension model in terms of interest, in particular (low-high) and attention to one another, (low - high). Pruitt has said that style of problem-solving is the best style of managing conflict effectively. But he did not give evidence of the impact of these styles on performance and productivity. Mastenbrook (1991), mentioned four styles based on his specialization of negotiation: aggressive, collaborative, avoidance and delay styles, he considered style of cooperation that negative recipe such as a submission or oblige unlike earlier concepts 
of cooperation [27], p. 153). Kurdeck (1994) introduces another model of styles of conflict management, which are problem-solving, confrontation, yielding and submissive, $\mathrm{He}$ applied this model in particular in marital conflict studies [28]. Finally, five-dimensions model was first of talked about is Mary Follett (1940), then Blake and Mouton (1964) came forward with administrative grid: forcing, withdrawal, Smoothing, compromising and problem solving, under directions of managers in interest of production and workers. Then (Thomas, 1976) modified concept of Blake and Mouton in the emphasis on the two major dimensions: cooperation and assertiveness and not interest to production and interest to people. Cooperation concerns of another party and assertiveness concerns of self [29]. Then Rahim [30], [31], has just two dimensions again for differentiation of the handling of conflicts after regard to concerns of self and other of interest to others, Compositions between these two dimensions produced five dimensions to deal with conflicts in the workplace. The researcher believes that focus on dimensions of (cooperation-competition), (production-workers), (collaboration-assertiveness) and (self-other), according to sequence of historical importance, Concern with Industrial Revolution, where interest was toward production and profitability and confirmation of competition among workers, as Taylor did, and experiences of motion and time studies. Then trend where humanitarian concern of worker in the industry. Hawthorn experiments appeared dimensionally particular interest of self and other. In spite of the labeled difference, in my opinion that all revolve in one sense. They are all synonyms for original one in which cooperation versus competition. Rahim [32] p. 218) reported that some behavioral scientists believe that the best style is integration style (problem solving), while others argue that conflict must manage and functional way, perhaps one of styles is more suitable in a particular situation, generally integrative and compromise styles are sometimes the best when dealing with strategic issues while rest of styles can use in dealing with everyday problems. This study adopted Rahim and Bonoma 1979 model, which based on the duality between self and other, has reached by confirmatory factor analysis on large samples of students, administrators driven five styles to resolve conflict management as follows: [8]pp.27-30, [33] p.504).

1- Integrative style, indicates of interest, self and other, also called way to solve problems, as it includes cooperation between parties in terms of clarity and exchange of information and check differences to reach an acceptable solution satisfies both conflicting sides.

2- Obliging style, where the smallest interest of self and top with others, this style is known as accommodating. Its emphasis on common characteristics to satisfy concerns of another party, a kind of Self-Sacrifice may take the form of self-generosity, charity and goodness of another party.

3- Dominant style, a person with a forcing style handles conflict in a win-lose fashion and does what it takes to win, with little regard for other person, known as well as Competing, he ignores needs, expectations of others and focus on winning his case just any price. The Supervisor may use authority to impose his will on subordinates.

4- Avoiding style, refers to the smallest interest of both self and other, also known as style oppressive Suppression linked to withdrawal, avoidance and evasion, he does not hear nor see nor speak preached in conflicting positions.

5- Compromising style, refers to the interest mediates all self-satisfying and pleasing others, it includes taking, giving and sharing, in which both sides stop something from their desires to work mutually acceptable decision for both, searching quickly for middle ground that satisfies both parties to resolve the problem.

6- Job satisfaction: [34], it is a "positive emotional state or pleasant resulting from evaluation of work experience." As defined by [35], as "it is a mental case includes all feelings related to extent of one's awareness of needs of job of being suited to him."

7- Organizational Commitment: [36], "self-actualize and its association with organization," it includes a concept for three interrelated trends: beliefs, goals of organization, accept its values, wish to make an effort for benefit of organization and wish to stay a member of it. [37] p. 19), "a strong belief in values and goals of the organization, and wish to exert effort for benefit of the organization and a strong want to continue working in it." [38], has identified it as "psychological state, describing employee relationship to the organization and its applications, and decision of wanting to continue to work with this organization."

8-Private and public sector: The public sector is government administration that aims to carry out state policies while private sector, which is managing private people or institutions that target greatest private activity. And it is the sum of institutions that are subject to capital of people or companies.

In the context of literature review results of studies are classifying as follows:

1- Some studies has found no relationships between conflict management styles, and organizational commitment (Al-Zahrani (2013) [39], another study found that causes of organizational conflict at Islāmic University are weak and do not lead to the emergence of a conflict between workers. Ahmed Alooah (2008) [40].

2- Some studies has found a negative relationships between some conflict management styles (integrative compromise) and job satisfaction. Al-Zahrani (2013). Other studies found a positive relationships between integrative style and job satisfaction. Chan, Huang and $\mathrm{Ng}$ (2008) [41], Nagat Bent Meshaal (2006) [42] has found a negative relationship between job satisfaction and organizational conflict.

3- Some studies found a positive relationships between conflict management styles and job satisfaction. [38], Ahmed Alooah (2008) [39], Shore and Martin, (1989) [43], Azeem, (2010) [44], Zeinabadi, (2010) [45], Suki and Suki, (2011) [46], Hayati and Kaniago, (2012) [47], Mohammed and Eleswed, (2013) [48].

4- Some studies found a positive relationships between job 
satisfaction and organizational commitment. Moynihan, Boswell, and Boudreau, (2000) [49], Mohammed and Eleswed, (2013) [48], Akanbi and Itiola, (2013) [50], Jamil Hassan Mohammad Qasim (2014) [51], Samar Mahmoud Mahmoud (2014) [52].Shore and Martin, (1989) [43], also found that organizational commitment was more closely related to moving from work than job satisfaction.

Rationale for the current study

1. Small number of studies that have focused on relationships between styles of managing conflict, job satisfaction, and organizational commitment. It also has not studied in terms of comparison between private and public organizations.

2. Some studies suffer from small sample sizes, and methods selected and limited number of variables under study. (Alzahrany, 2013), (Hang and Hhan 2007), (Shore and Martin 1989) (Suki and Suki 2001)

3. The problem of homogeneity in different organizations or culture. (Alzahrany, 2013).C- Research model

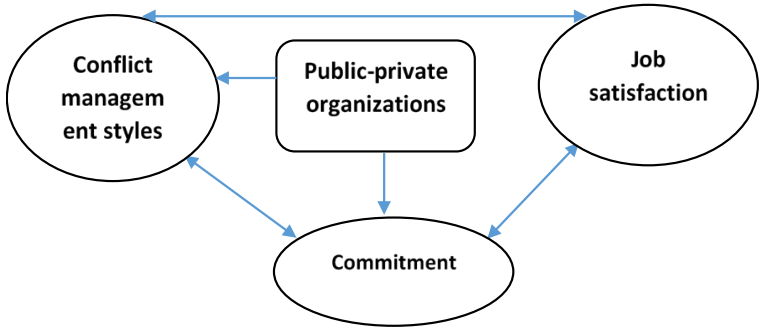

Figure 1. Research model

From reviewing literature, we can draw a research model Fig.1 where two samples are interesting of comparing all variables, and investigating relationships between them.

Hypothesis of study:

1. There are not significant relationships between conflict management styles, job satisfaction, and organizational commitment.

2. There are not significant differences between private and public organizations in conflict management styles, job satisfaction, and organizational commitment.

3. There are significant differences between correlation coefficients (private - public) organizations in relationships between conflict management styles and job satisfaction.

4. There are significant differences between the correlation coefficients (private - public) organizations in relationships between conflict management styles and organizational commitment.

\section{Research Methodology}

1-Subjects: study of selected samples of private and public organizations in a way convenience sample, it's used to describe a sample in which elements selected from target population because accessibility or convenience to researcher (Ross 2005, p.8) [53], it's saving time and costs, where selected individuals who are in work day. It has printed 600 research forms. Questionnaires distributed in period from March 2014 till May 2014. Amount forms applicable in field of Minia University Forms 234 out of 300, after sorting and exclusion forms incomplete or compromised by respondent (response set), reached number of forms (198) employees. For private sample selected from a number of production companies in the industrial zone (Tenth of Ramadan -Egypt) Helel and Negma Zahabiya Company, Back Line for production of cardboard and Kandil Paper Industries). Number of forms received 150 forms out of 300, after reviewing arrived (131). Number of males in public 122 , by $61.6 \%$ of total sample size $(\mathrm{n}=198)$, while males in production companies amounted to 119 individuals, $90.8 \%$ of total sample size $(n=131)$. In terms of age variable number of whose ages less than 28 years in public organization are 45 by $22.7 \%$, Ages between 29 and 42 years amounted to 88 individuals by $44.4 \%$, greater than 43 years amounted to 65 individuals by $32.8 \%$. While in production companies were preparing reconstruction of at least 28 years amounted to 41 individuals by $31.5 \%$, and among ages $29-42$ years amounted to 68 individuals by $52.3 \%$, ages of 43 years amounted to 21 individuals by $16.2 \%$., Thus for rest of demographic variables although these ratios distributed samples of study does not met homogeneity between two samples, which were all $x_{2}$ values respectively $\{34.36$ (between sex)-11.67 (between age categories) -66.11 (occupations)-15.33 (experience years)-0.55 (social status)-24.8 (education levels)-10.81 (socio-economic level)\} of differences between two samples (private -public) where's all variables are significant at the level 0.05 except for social status variable significance was not. This result expected, even if completed all homogeneity properties, due to productive sector care only (private), because of young age of its staff, poor education, lack years of working and relying largely on males, compared to other sample (public). So homogeneity is difficult between the two samples.

2-tools of Study: 1-conflict management styles questionnaire, (Rahim, 1983) [27], [which consists of 28 items translated and add a range of items from administrative and cultural experience of researcher and terms of other questionnaires added four items: item number 30- I believe "to oppressed and not oppressor". Item number 31- I used the method of "divide two halves between us to resolve conflict". Item number 33- I prefer method of "take them sound" to impose my opinion. Item No. 35-altruism others on myself. Add item No. 38 of Dudley Weeks questionnaire (Weeks, 1994), because of its importance in our culture in most cases, what we resort to a third-party help us in resolving our conflicts, which is in this Form No. 36-" I asking intervention of other parties when severe conflict". And added the rest items from (Putnam and Wilson,1982) questionnaire, items number 29-32-34-37-38-39-40 figures in the current form, which distributed across dimensions of questionnaire two items for avoidance, two for oblige, one for integration, two for dominance style. Then total item became 40 items. Psychometric methods for five conflict management styles where's Cronbach alpha $(\alpha)$ for 
(private-public samples) avoidance style 0.74, 69 respectively, oblige $0.65,69$ and for compromise $0.57,0.61$ and integrative $0.64,0.69$ finally dominance $0.67,0.67$. Construct validity by exploratory factor analysis VARIMAX orthogonal rotation carried out of every style loadings were between $0.38-0.72$ for avoidance, 0.32-0.65 for oblige, 0.32-0.79 for dominance except items no. 5, 15 have loadings less than 0.30 So they omitted from questionnaire. Total items became 38 and respondents asked to write down on a five-point response scale, extents to which very agree to very disagree.

3- Job satisfaction. This measure developed by Warr, Cook and Wall (1979) [54], It scoring to give a single index of Overall Job Satisfaction, Intrinsic Job Satisfaction covers people's affective reactions to job features that are integral to the work itself (e.g. variety, opportunity to use one's skills, autonomy); where Extrinsic Job Satisfaction covers features external to work itself (e.g. pay, style of managing). Job Satisfaction Scale consists of 15 items, and respondents are asked to write down on a seven-point response scale (modified to five-point scale) the extent to which they satisfied or dissatisfied with each. (Stride, wall and Catley 2007) [55] pp. 13-14). Reliability of Cronbach $(\alpha)$ for this research was 0.87 , and all the item loadings were in one factor $(0.41-0.75)$ before rotating.

4- Organizational commitment. This measure developed by Cook and Wall (1980) [56], overall concept of organizational commitment refers to people's affective reactions to their employing organization. It can be scored to provide a single index of Overall Organizational Commitment, containing nine items. Respondents asked to write down on a five-point response scale the extent to which they agree or disagree with each statement. Reliability of Cronbach $(\alpha)$ for this research was 0.69 where item loadings in one factor (0.41-0.74) before rotating.

\section{Results}

Table 1. Descriptive statistics for variables

\begin{tabular}{|c|c|c|}
\hline variables & mean & Sd. \\
\hline Avoidant private & 16.83 & 6.32 \\
Public & 18.22 & 5.19 \\
\hline Obliging private & 19.40 & 5.10 \\
Public & 19.36 & 5.36 \\
\hline Compromise private & 21.02 & 4.10 \\
Public & 20.63 & 4.81 \\
\hline Integrative private & 22.29 & 3.69 \\
Public & 21.89 & 4.79 \\
\hline Dominance private & 14.86 & 4.94 \\
Public & 15.05 & 5.60 \\
\hline Job satisfaction private & 37.07 & 10.25 \\
Public & 35.77 & 10.24 \\
\hline Commitment private & 22.79 & 5.13 \\
Public & 21.92 & 5.08 \\
\hline
\end{tabular}

We used MANOVA method because it can employed to control overall Type I Error rate while still providing a means of assessing differences on each dependent variable both collectively and individually [57] p.380). Table (2) displays results of Box‘s $M$ test of equality of covariance.
This test obtained to test homogeneity of variance-covariance matrices. results of the Box's M test showed significant differences in variances among groups. $\mathrm{P}$ $=0.005$. We should accept alternative hypothesis that covariance matrices of dependent variables are unequal across groups, this result due to difficulty of choosing two samples on base of homogeneity. With respect to equality of error variance, all factors met this assumption. Wilks'Lambda $(p=.971)$ which is greater than 0.05 . From table. 3 we conclude that there are no statistically significant differences in conflict management styles between private and public organizations. Therefore, first hypothesis of this research accepted.

Table 2. homogeneity test

\begin{tabular}{|c|c|}
\hline Box‘s M for homogeneity & 52.09 \\
\hline F value & 1.81 \\
df & 1 \\
Sig. & 0.005 \\
\hline Wilks lambda & 0.971 \\
F & 1.31 \\
df for error & 313 \\
sig & 0.56 \\
\hline
\end{tabular}

Table 3. ANOVA results

\begin{tabular}{|c|c|c|c|c|c|}
\hline Variables & $\begin{array}{c}\text { Sum. } \\
\text { squares }\end{array}$ & df & $\begin{array}{c}\text { Mean. } \\
\text { squares }\end{array}$ & $\begin{array}{c}\text { F } \\
\text { value }\end{array}$ & Sig. \\
\hline Avoidant & 147.88 & 1 & 147.88 & 3.95 & 0.05 \\
Obliging & 0.11 & 1 & 0.11 & 0.00 & n.s \\
Compromise & 11.82 & 1 & 11.82 & 4 & n.s \\
Integrative & 11.85 & 1 & 11.85 & 0.57 & n.s \\
Dominant & 2.89 & 1 & 2.89 & 0.59 & n.s \\
Job satisfaction & 128.77 & 1 & 128.77 & 0.10 & n.s \\
commitment & 58.01 & 1 & 58.01 & 2.23 & n.s \\
\hline
\end{tabular}

Table(3) shows that there are no significant differences between private and public organizations in all the variables, except for the avoidance of conflict management style, the different was toward public group $(\mathrm{M}=18.22, \mathrm{SD}=5.19)$. For two samples private and public correlation coefficients table (4) showed a positive relationships between conflict management styles and organizational commitment at significant level $p \leq 0.05$, Except for a negative relationship between dominant style and commitment $(\mathrm{r}=-0.243)$. Where relationships between conflict management styles and job satisfaction there were no significant correlations except negative relationship between dominant style and commitment $(r=-0.318)$ for private sample only. A positive relationships between job satisfaction and commitment for private and public samples $(\mathrm{r}=0.60,0.28)$, which indicates a strong correlation between the two variables in private sample. To test whether these correlations are significantly different from each other, correlations transformed, by what called Fisher's $r$ to $Z$ transformation, effect of this transformation is to make sampling distribution of transformed coefficient nearly normally distributed, it also makes variance of correlation coefficient about same regardless value of population correlation [58] p.50). So table (4) showed that there are significant differences 
between two groups (private and public) in styles of avoidance, compromise and dominance in relationships between styles of conflict management and job satisfaction toward public organization. It also found significant differences between two groups in relationship between avoidance style and job satisfaction in relationships between conflict management styles and organizational commitment toward public organization, and toward private organization in relationship between job satisfaction and organizational commitment.

\section{Discussion}

In this research, we examined relationships between conflict management styles, job satisfaction, and organizational commitment. It involved two groups of private and public organizations. preliminary findings are quite interesting and give motivation to pursue in-depth analyses of research data, results of study styles for Conflict Management correlated with job satisfaction, as well as with organizational commitment, and that in public group which is a service-governmental organization where administrative routine and presence of large numbers of employees may increase need for real work, which will entail administrative conflicts, It is strange that this relationship will be a positive, which indicates that satisfaction of work with that type of conflict management, whether positive or negative ones. This result is consistent with findings of Huang and $\mathrm{Ng}$ Chan 2007 and Alzahrany, 2013 where they found a significant positive relationship between integrative and compromise styles of conflicts management and job satisfaction. Contrary to findings of Alzahrany, 2013 where he did not find a relationship between the styles of conflict management and organizational commitment and Nagat 2006, which reached a negative relationship between job satisfaction and organizational conflict. Which consistent with findings Aloha 2008, he found a positive relationship between styles of conflict management and job satisfaction. Except for dominance style in managing conflict and which may result in a lack of loyalty and commitment to organization. It is the same as found in private organizations, which makes us to explain that resolution of conflicts based on level of administrative or ownership to deal with staff, work in Egyptian environment may result in a lack of organizational commitment, which ignore needs and expectations of workers. study also showed that style of avoidance, when resolution of conflicts and in group of public organizations and this in turn reflected in nature of employees, altruism safety and not to enter into conflicts may not harvested them. Employee and control by both president actually has two faces of the same coin avoidance where withdrawal linked to repression and evasion or delay even best and nature of Egyptian society that in time of conflict is often a third-party intervenes to resolve. Study of relationship is between styles of conflict management and job satisfaction. Also, showed that public organizations using avoidance, dominant and compromise styles when dealing with conflicts compared to organizations profitability. In other words, job satisfaction achieved in these organizations by following styles of resolving conflicts at work through avoidance, compromise, impose dominant and power. In the relationship between styles of conflict management and organizational commitment to public organizations found that workers in public organizations more avoidance than private organizations. In other words, loyalty and organizational commitment achieved through public organizations when follow style of avoidance and not to enter into direct conflict with others. Results also showed a significant relationship between job satisfaction and organizational commitment where private organizations more satisfaction and organizational commitment for public organization which caused by high wages compared to public organizations. Study is consistent with findings of Shore and Martin 1989, Moynihan et al 2000, Azeem 2010, Zeinabadi 2010, Suki and Suki 201, Hyati and Kaniago 2012, Mohammed and Eleswed 2013, Akanbi and Itiola 2013, Gameel Hassan 2014 and Samar Mohammed 2014, where they founded positive relationships between job satisfaction and organizational commitment.

Table 4. the differences between two independent correlation Coefficients

\begin{tabular}{|c|c|c|c|c|c|c|}
\hline \multirow[b]{2}{*}{ Variables } & \multicolumn{2}{|c|}{ Job satisfaction } & \multirow[b]{2}{*}{$Z$ value } & \multicolumn{2}{|c|}{ Commitment } & \multirow[b]{2}{*}{$Z$ value } \\
\hline & $\begin{array}{r}\text { Private } \\
(\mathrm{n}=131)\end{array}$ & $\begin{array}{l}\text { public } \\
(\mathrm{n}=198)\end{array}$ & & $\begin{array}{r}\text { Private } \\
(\mathrm{n}=131)\end{array}$ & $\begin{array}{l}\text { public } \\
(\mathrm{n}=198)\end{array}$ & \\
\hline 1. Avoidant & -0.131 & $0.204^{* *}$ & $2.98^{* *}$ & -0.114 & $0.194^{* *}$ & $2.74^{* *}$ \\
\hline 2. Obliging & 0.122 & $0.316^{* *}$ & 1.8 & 0.112 & $0.177^{*}$ & 0.58 \\
\hline Compromise & -0.019 & $0.355^{* *}$ & $3.43^{* *}$ & 0.039 & $0.218^{* *}$ & 1.61 \\
\hline Integrative & 0.112 & $0.269^{* *}$ & 1.44 & 0.117 & $0.196^{* *}$ & 0.71 \\
\hline 5. Dominant & -0.123 & $0.164^{*}$ & $2.54^{* *}$ & $-0.318^{* *}$ & $-0.243^{* *}$ & 0.72 \\
\hline 6. J. satisfaction & ------ & -------- & ----- & $0.60^{* *}$ & $0.28^{* *}$ & $3.65^{* *}$ \\
\hline
\end{tabular}

$*$ P. value $\leq 0.05, * *$ P. value $\leq 0.01$ 


\section{Limitations}

Generally studies of conflicts in workplace suffer from a lack of credibility in data collected, and it came from difficulty of respondent interest, which may due to a number of reasons: unwillingness of individuals to discuss problems and then may not wish to take part, as they may not have a thorough understanding of conflict, as people may wish to ignore conflict and forgotten, this belief reduces impact, was afraid to discuss conflict in fear of its effects on job. Adding problem of homogeneity between private and public organizations, we can't generalize results of present study. Future research directions should consider checking psychometric (classical and modern of conflict style questionnaire in Egypt.

\section{REFERENCES}

[1] De Dreu,C.K.W., Van Dierendonck, D., and De Best-Waldhober, M.(2003) Conflict at Work and Individual Well-Being In Schabracq, M.J., Winnubst, J.A.M., and Cooper, C.L. (Eds.). The Handbook of Work and Health Psychology. Second Edition. England, John Wiley \& Sons Ltd.

[2] Thomas, K.W., (1992) Conflict and negotiation process in organization. In Dunnette, M.D, Hough, L.M., (Eds.). Handbook of industrial and organizational psychology. Second edition, Vol.3, Consulting psychological press: Palo Alto, CA, 651-717.

[3] Spector, P.E and Burk-Lee, V. (2008) Conflict, Health and wellbeing. In. DE Dreu, C.K.W., and Gilfand, M.J. (Eds.). The Psychology of Conflict and Conflict Management in Organizations. New York, Lawrence Erlbaum Associates.

[4] De Dreu,C.K.W., Harinck, F. Van Vianen, A.E.M. (1999) Conflict and performance in groups and organizations. International Review of Industrial and Organizational Psychology, 14, 376-405.

[5] De Dreu,C.K.W., and Beersma, B. (2005) Conflict in organizations: Beyond effectiveness and performance. European Journal of Work and Organizational Psychology, 14 (2), 105-117.

[6] Deutsch, M. (2006). Introduction. In Deutsch, M., Coleman, P.T and Marcus, E.C. (Eds.) the handbook of conflict resolution, theory and practice.nd 2 edition. New York, John Wiley \& Sons,

[7] The Holy Qur'an.

[8] Rahim, M.A. (2001) Managing Conflict in Organizations. Third Edition, London, Quorum Books.

[9] Mcshane, S.L. and Von Glinow,M.A (2010) Organizational behavior. New York, Mc Graw-Hill/Irwin.

[10] Baron, R. A. (1990) Conflict in organizations. In K. R. Murphy and F. E. Saal (Eds.),_Psychology in organizations: Integrating science and practice. (pp. 197-216).Hillsdale, NJ: Erlbaum.
[11] Pondy, L. R. (1967) Organizational conflict: Concepts and models. Administrative Science Quarterly,12, 296

[12] Ting-Toomey, S. (1985) toward a theory of conflict and culture. In W.B. Gudykunst, L.P. Stewart \& S. Ting-Toomey (Eds.). Communication Culture and Organization Processes, 71-85. Beverly Hills, CA: Sage.

[13] Rahim, M.A. and Magner, N.R. (1995) Confirmatory factor analysis of the styles of handling interpersonal conflict: First-order factor model and its intervariance across groups. Journal of Applied Psychology, 80, 122

[14] Marquis B.K. \& Huston C.J. (1996) Leadership Roles and Managers Function in Nursing. 2nd edition. Lippincott, Philadelphia, PA.

[15] Thompson, L. (1998) the mind and heart of the negotiation. Upper Saddle River, NJ: Prentice-Hall.

[16] De Dreu, C.K.W., and Gilfand,M.J.(2008) Conflict in the workplace sources, functions, and dynamics across multiple levels of analysis. In DE Dreu, C.K.W., and Gilfand,M.J. (Eds.). The Psychology of Conflict and Conflict Management in Organizations. New York, Lawrence Erlbum Associates.

[17] Johnson, D., \& Johnson, R. (2012) Restorative justice in the classroom: Necessary roles of cooperative context, constructive conflict, and civic values. Negotiation and Conflict Management Research, 5, 4-28.

[18] Mukundan, S., and Zakkariya, K.A., (2013) Emotion intelligence as a determinant of conflict style adoption of managers: A theoretical perspective. International Journal of Social Science \& Interdisciplinary Research, 2, 2, pp.148-154.

[19] Nicholson, N. (1998) The Blackwell Encyclopedic Dictionary of Organizational Behavior. New York, Blackwell Publishers Ltd.

[20] Olekalns,M., Putnam, L.L., Weingart, L.R., and Metcalf, L. (2008) In. DE Dreu, C.K.W., and Gilfand, M.J. (Eds.). The Psychology of Conflict and Conflict Management in Organizations. New York, Lawrence Erlbum Associates.

[21] Putnam, L.L. and Wilson, C.E. (1982) Communication strategies in organizational conflicts: Reliability and validity of a measurement scale. Communication Year Book, $6,629-652$.

[22] Hocker J.L., and Wilmat W.W. (2010) Interpersonal conflict. Boston: McGraw Hills.

[23] Lawrence, P. R., \& Lorsch, J. W. (1967a). Differentiation and integration in complex organizations. Administrative Science Quarterly, 12, 1-47.

[24] Hall, J. (1969). Conflict management survey: A survey of one's characteristic reaction to and handling conflict between himself and others. Canoe, TX: Teleometrics International.

[25] Van de Vliert, E. (1997). Complex Interpersonal Conflict Behavior: Theoretical Frontiers, Psychology Press, Hove, England.

[26] Pruitt, D. G. (1983) Strategic choice in negotiation. American Behavioral Scientist, 27,167-194.

[27] Leeds, C.A. (1992) The French approach to handling conflicts and to negotiating: certain notable features. In Fenn, P. and Gameson, R. (Eds.) construction conflict management and 
resolution. Proceedings of the first international construction management conference, the University of Manchester, institute of science and technology (UMIST). 25-27 September.

[28] Kurdek, L. A. (1994). Conflict resolution styles in gay, lesbian, heterosexual nonparent, and heterosexual parent couples. Journal of Marriage and the Family, 56, 705-722.

[29] Thomas, K. W. (1976). Conflict and conflict management. In M. D. Dunnette (Ed.), Handbook of industrial and organizational psychology. Chicago: Rand-McNally.

[30] Rahim, M. A., \& Bonoma, T. V. (1979) Managing organizational conflict: A model for diagnosis and intervention. Psychological Reports, 44, 1323-1344.

[31] Rahim, M.A. (1983) A Measure of Styles of Handling Interpersonal Conflict. The Academy of Management Journal, 26, 2, pp. 368-376.

[32] Rahim, M.A. (2002) Toward a theory of manageing organizational conflict. The international Journal of Conflict Management, 13, 3,206-235.

[33] Aamodt, M.G. (2010) Industrial/Organizational Psychology: An Applied Approach. Sixth Edition, USA, WADWORTH CENGAGE Learning.

[34] Luthans, F. (1998).Organisational Behaviour. 8th ed. Boston: Irwin McGraw-Hill.

[35] Evans L 2001. Delving deeper into morale, job satisfaction and motivation among education professionals: re-examining the leadership dimension. Educational Management and Administration, 29:291-306

[36] Porters, L.W., Steers, R.M., Mowday, R.T., \& Boulin, P.V. (1974). Organizational commitment, job satisfaction, and turnover among psychiatric technicians. Journal of Applied Psychology, 59, 603-609.

[37] Mowday, R.T., Steers, R., \& Porter, L. (1982). Organizational linkages: The psychology of commitment, absenteeism, and turnover. New York: Academic Press

[38] Meyer, J.P., \& Allen, N.J. (1991). A three-component conceptualization of organizational commitment. HumanResource Management Review, 1, 61-98

[39] Alzahrani, M. (2013) A Comparative Study of the Relationships between Conflict Management Styles and Job Satisfaction, Organizational Commitment, and Propensity to Leave the Job among Saudi and American Universities 'Faculty Members. A Dissertation Submitted to the Faculty of The College of Design and Social Inquiry, Florida Atlantic University, Boca Raton, Florida.

[40] Alloah, A.Y (2008). Organizational conflicts and their impact on job satisfaction, a comparative study of the views of workers in Al-Azhar University and the Islamic. Master Thesis, unpublished, Faculty of Commerce, the Islamic University of Gaza.

[41] Chan K.W, Huang X and NG P.M. (2008) Managers' conflict management styles and employee attitudinal outcomes: The mediating role of trust. Asia Pacific Journal of Management, (2008) 25:277-295.

[42] Al Zawafry N.M. (2006) Job satisfaction and organizational conflict relationship, "An Empirical Study of the King Saud University staff. Master Thesis, unpublished, Faculty of Management, King Saud University.
[43] Shore, L.M and Martin, H.J (1989) Job satisfaction and organizational commitment in relation to work performance and turnover intentions. Human relations, 42, 7, 625-638.

[44] Azeem, S.M. (2010) Job Satisfaction and Organizational Commitment among Employees in the Sultanate of Oman. Psychology, 1, 295-299.

[45] Zeinabadi, H. (2010) Job satisfaction and organizational commitment as antecedents of Organizational Citizenship Behavior (OCB) of teachers. Procedia Social and Behavioral Sciences, 5, 998-1003.

[46] Suki, N.M and Suki, N.M (2011) Job satisfaction and organizational commitment: The effect of gender. International Journal of Psychology Research, 6, 5, 1-15.

[47] Hayati, K. and Kaniago, I. (2012) Islamic Work Ethic: The Role of Intrinsic Motivation, Job Satisfaction, Organizational Commitment and Job Performance. Procedia - Social and Behavioral Sciences, 65,272-

[48] Mohammed, F. and Eleswed, M. (2013) Job Satisfaction and Organizational Commitment: A Correlational Study in Bahrain. International Journal of Business, Humanities and Technology.3, 5, pp.43-53.

[49] Moynihan, L. M., Boswell, W. R. \& Boudreau, J. W. (2000) the influence of job satisfaction and organizational commitment on executive withdrawal and performance, (CAHRS Working Paper \#00-16). Ithaca, NY: Cornell University, School of Industrial and Labor Relations, Center for Advanced Human Resource Studies.

[50] Akanbi, P.A. and Itiola, K.A. (2013) Exploring the Relationship between Job Satisfaction and Organizational Commitment among Health Workers in Ekiti State, Nigeria. Journal of Business and Management Sciences, Vol. 1, No. 2, $18-22$.

[51] Qasim J.H. (2014) Job satisfaction and organizational justice and organizational loyalty to their relationship. Master Thesis, unpublished, Faculty of Commerce, University of Menoufia.

[52] Mahmoud, S.M. (2014). Servant leadership and its relationship to job satisfaction and organizational commitment of some members of the teaching staff of the Egyptian universities. Master Thesis, unpublished, Faculty of Commerce, University of Menoufia.

[53] Ross, K.N (2005). Sample design for educational survey research. International Institute for Educational Planning, UNESCO.

[54] Warr P.B, Cook J.D \& Wall TD (1979). Scales for the measurement of some work attitudes and aspects of psychological well-being. Journal of Occupational Psychology, 52, 129-148.

[55] Stride, C wall, T.D and Catley, N. (2007) Measures of the job satisfaction, organizational commitment, mental health and job-related well-being, a benchmarking manual. Second edition, England, John Wiley \& Sons Ltd.

[56] Cook J and Wall T.D (1980). New work attitude measures of trust, organizational commitment and personal need non-fulfilment. Journal of Occupational Psychology, 53, 3952.

[57] Hair, J., Black, B. Babin, B., Anderson, R. and Tatham, R. (2006). Multivariate Data Analysis (6 ${ }^{\text {th }}$ edition). Upper Saddle River, NJ: Prentice-Hall. 
[58] Cohen, J. Cohen P., West S.G., and Aiken, L.S (2003) Applied Multiple Regression/Correlation Analysis for the
Behavioral Sciences, Third Edition, London, Lawrence Erlbaum Associates, Publishers. 